\title{
Removal of heavy metals from waste water using a hybrid membrane process
}

\author{
Štefan Sabo, Tomáš Bakalár, Milan Búgel, Henrieta Pavolová \\ Technical University of Košice, Faculty of Mining, Geology, Process Control and Geotechnologies
}

(c) 2015 Authors. This is an open access publication, which can be used, distributed and reproduced in any medium according to the Creative Commons CC-BY 4.0 License requiring that the original work has been properly cited.

Soil and water pollution by heavy metals is currently a very important problem in environmental and other sectors. The origin of metals in water may be of either natural character (erosion of rocks and sediments, leaching of mineral resources) or anthropogenic character (mining and extraction of metals, industry, agriculture, etc.) (Martins et al. 2010). Many heavy metals, such as $\mathrm{Pb}, \mathrm{Cd}, \mathrm{Cu}, \mathrm{Zn}$, etc., are the most polluting factors in industrial wastewater and may get into the ground water. Subsequently they are bio-accumulated in living organisms and cause various diseases and disorders (Jamil et al. 2010). These problems need to be responded by developing new and more efficient methods for wastewater treatment (Martins et al. 2010). In practice several methods are used for removal of heavy metals from water. One of the promising methods for the removal of metal ions from water is a hybrid membrane processes. This method includes two processes - adsorption of metal ions on the natural zeolite and microfiltration of zeolite suspension through ceramic membrane. Experiments were carried out using model solutions containing $\mathrm{Cu}^{2+}$ ions (from $\mathrm{CuSO}_{4} \cdot 5 \mathrm{H}_{2} \mathrm{O}$ and $\mathrm{Cu}\left(\mathrm{NO}_{3}\right)_{2} \cdot 3 \mathrm{H}_{2} \mathrm{O}$ ) and $\mathrm{Zn}^{2+}$ ions (from $\mathrm{ZnSO}_{4} \cdot 7 \mathrm{H}_{2} \mathrm{O}$ and $\left.\mathrm{Zn}\left(\mathrm{NO}_{3}\right)_{2} \cdot 6 \mathrm{H}_{2} \mathrm{O}\right)$.

In the experiments zeolite from Nižný Hrabovec localization (Zeocem JSC Bystré), Slovakia was used. Zeolite is mainly composed of mineral clinoptilolite (84\%), other mineral are cristobalite $(8 \%)$, clay (4\%) and plagioclase (3-4\%). Its structure is formed by three-dimensional network. Clinoptilolite is composed from silicate tetra- hedron $\mathrm{SiO}_{4}{ }^{4-}$ bound together by oxygen atoms, where part of the $\mathrm{Si}$ atoms is replaced with aluminum $\mathrm{AlO}_{4}{ }^{5-}$. This creates space structures with a number of cavities and channels, in which are accommodate metal cations and water molecules. The total volume of cavities is $24-32 \%$. Zeolite has a bulk density of $1600-1800 \mathrm{~kg} \cdot \mathrm{m}^{-3}$, a specific gravity of $2200-2440 \mathrm{~kg} \cdot \mathrm{m}^{-3}$ and the specific surface of 30-60 $\mathrm{m}^{2} \cdot \mathrm{g}^{-1}$ (www.zeocem.com).

Adsorption experiments on model solutions were performed with the zeolite with particle size 20 microns. Before and after the experiments the concentrations of $\mathrm{Cu}$ and $\mathrm{Zn}$ were determined by atomic absorption spectrophotometry (AAS) using iCE 3300 AA Spectrometer Thermo Scientific. Solutions with concentrations of $10-5000 \mathrm{mg} \cdot \mathrm{L}^{-1}$ were prepared from each of the chemicals. The solutions were shaken with $1 \mathrm{~g}$ of zeolite in 100 $\mathrm{ml}$ PET flasks on a shaker for 2.5 hours at $25^{\circ} \mathrm{C}$ and $220 \mathrm{rpm}$. The amounts of metals ( $\mathrm{Cu}$ or $\mathrm{Zn})$ in solutions were measured after stabilization, filtration and required dilution by AAS. The equilibrium between the concentration in solution and the adsorbed substance was evaluated using Langmuir, Freundlich and Redlich-Peterson models. According to the results of the adsorption experiments zeolite adsorbed of both the nitrates ions $\left(\mathrm{Cu}^{2+}\right.$ and $\mathrm{Zn}^{2+}$ ) (equilibrium concentrations $1.48 \mathrm{mg} \cdot \mathrm{g}^{-1}$ and $1.49 \mathrm{mg} \cdot \mathrm{g}^{-1}$, respectively) best and the sulfate ions ( $0.34 \mathrm{mg}^{-\mathrm{g}^{-1}}$ and $0.85 \mathrm{mg} \cdot \mathrm{g}^{-1}$, respectively) less. Due to better adsorption capacities of zeolite for ions derived from nitrates, further experiments were made from chemicals $\mathrm{Cu}\left(\mathrm{NO}_{3}\right)_{2} \cdot 3 \mathrm{H}_{2} \mathrm{O}$ and $\mathrm{Zn}\left(\mathrm{NO}_{3}\right)_{2} \cdot 6 \mathrm{H}_{2} \mathrm{O}$. 
The next step was microfiltration of suspension of zeolite since a hybrid process for removal of $\mathrm{Cu}$ and $\mathrm{Zn}$ ions was used. Microfiltration was carried out at a constant pressure of $50 \mathrm{kPa}$, the flow rate of suspension $2.2 \mathrm{~m} \cdot \mathrm{s}^{-1}$ and various concentrations of zeolite $\left(1-6 \mathrm{~g} \cdot \mathrm{L}^{-1}\right)$. Tubular Membralox ceramic membrane was used, with length of $25 \mathrm{~cm}$, internal diameter of $0.5 \mathrm{~cm}$, external diameter of $0.7 \mathrm{~cm}$ and porosity of $50 \mathrm{~nm}$. Active surface of the membrane was $49.48 \mathrm{~cm}^{2}$. Zeolite was added to the solution of ions circulating in the cross-flow microfiltration system. Metal ions were adsorbed by zeolite and the suspension was filtered by the membrane. The adsorbed metal remained circulating in the system and the permeat was purified water. Using this method, at suitable selection of the experimental conditions, up to $90-100 \%$ of metal ions can be removed from the solution.

\section{REFERENCES}

Martins A., Mata T.M., Gallios G.P., Václaviková M. \& Stefusova K., 2010. Modeling and simulation of heavy metals removal from drinking water by magnetic zeolite. [in:] Václavíková M., Vitale K., Gallios G.P., Ivanicová L. (eds), Water Treatment Technologies for the Removal of High-Toxicity Pollutants, Springer Netherlands, 61-83.

Jamil T.S., Ibrahim H.S., Abd El-Maksoud I.H. \& El-Wakeel S.T., 2010. Application of zeolite prepared from Egyptian kaolin for removal of heavy metals. I: Optimum conditions. Desalination, 258. 34-40. 